\title{
Phytochemical and Biological Activities of Four Wild Medicinal Plants
}

\author{
Anwar Ali Shad, ${ }^{1}$ Shabir Ahmad, ${ }^{2}$ Riaz Ullah, ${ }^{3}$ Naser M. AbdEl-Salam, ${ }^{4}$ H. Fouad, ${ }^{4,5}$ \\ Najeeb Ur Rehman, ${ }^{6}$ Hidayat Hussain, ${ }^{6}$ and Wajid Saeed ${ }^{1}$ \\ ${ }^{1}$ Agricultural Chemistry Department, The University of Agriculture, Peshawar, Khyber Pakhtunkhwa 25000, Pakistan \\ ${ }^{2}$ Department of Chemistry, Islamia College Peshawar, Khyber Pakhtunkhwa 25000, Pakistan \\ ${ }^{3}$ Department of Chemistry, Government College Ara Khel, FR Kohat, Khyber Pakhtunkhwa 26000, Pakistan \\ ${ }^{4}$ Riyadh Community College, King Saud University, Riyadh 11437, Saudi Arabia \\ ${ }^{5}$ Department of Biomedical Engineering, Faculty of Engineering, Helwan University, Helwan 11790, Egypt \\ ${ }^{6}$ UoN Chair of Oman's Medicinal Plants and Marine Natural Products, University of Nizwa, P.O. Box 33, Birkat Al Mauz, \\ 616 Nizwa, Oman
}

Correspondence should be addressed to Riaz Ullah; afridiriaz@yahoo.com

Received 20 June 2014; Revised 16 August 2014; Accepted 2 September 2014; Published 13 October 2014

Academic Editor: Paula B. Andrade

Copyright (C) 2014 Anwar Ali Shad et al. This is an open access article distributed under the Creative Commons Attribution License, which permits unrestricted use, distribution, and reproduction in any medium, provided the original work is properly cited.

The fruits of four wild plants, namely, Capparis decidua, Ficus carica, Syzygium cumini, and Ziziphus jujuba, are separately used as traditional dietary and remedial agents in remote areas of Khyber Pakhtunkhwa, Pakistan. The results of our study on these four plants revealed that the examined fruits were a valuable source of nutraceuticals and exhibited good level of antimicrobial activity. The fruits of these four investigated plants are promising source of polyphenols, flavonoids, alkaloids, terpenoids, and saponins. These four plants' fruits are good sources of iron, zinc, copper, manganese, selenium, and chromium. It was also observed that these fruits are potential source of antioxidant agent and the possible reason could be that these samples had good amount of phytochemicals. Hence, the proper propagation, conservation, and chemical investigation are recommended so that these fruits should be incorporated for the eradication of food and health related problems.

\section{Introduction}

The wild plants play significant role in the suppression of dietary and pathogen related ailments of native people since long before recorded history. Latest research investigation observed that the bioactive and antioxidant potentials of these plants are attributed to the presence of polyphenols, flavonoids, lignins, alkaloids, terpenoids, carotenoids, vitamins, and so forth [1-3]. They help in maintaining the nutritional quality and shelf life of foods by inhibiting lipid oxidation, minimizing rancidity, and removing toxic oxidative products [4-7]. Similarly, phenolic compounds play important role in antioxidant activity and resistance against pests and other species dissemination.

The emergent population coupled with poverty and natural disasters interrogates how the native people of Khyber Pakhtunkhwa are able to cope with the challenge of easy access to food and medicine. Despite the government's mammoth expenses on the livelihood of common people, the provision of balanced food and modern healthcare to rural people is still a far-reaching goal [8]. Hence, it is recommended that researchers should resort to forms of nutraceuticals mainly in the native plant species to overcome the constraints of human necessities. Phytochemicals and minerals ingredients are necessary for virtually all reactions to occur in the body [9-11]. While each has its own unique properties, they work synergistically to ensure reactions in the body occur appropriately [12].

Southern parts of Khyber Pakhtunkhwa are blessed with plenty of wild plants which have very significant role in the daily life of rural people. The main areas of this region include Kohat, Karak, Bannu, and Dera Ismail Khan. In this regard, a project was designed to investigate four different food plants (Ficus carica, Syzygium cumini, Capparis decidua, 
and Ziziphus jujube) that are separately used in cuisines either in fresh form or in semicooked form. It was also observed that some people of the subject areas use them for the eradication of various diseases. The botanical description of each examined plant is described briefly as follows.

Ficus carica L. is important species of Moraceae family which is locally known as Inzar in Pushto. It is widely grown throughout the temperate world, both for its fruit and as an ornamental. The fruits and leaves parts of this plant exhibited significant level of antioxidant and antimicrobial activity [13, 14]. The fruit has a laxative effect and the daily uses of dried fig enhanced the antioxidant capacity in plasma [15]. Similarly, Jamun (Syzygium cumini L. Skeels) belongs to Myrtaceae family and is considered the richest nutritional source. It contains flavonoids, tannins, triterpenoids, carotenoids, and sitosterols. The extracts of this plant exhibited various activities including cytotoxic, anti-inflammatory, anticancer, and antidiabetic activities [16].

The fruit of Capparis decidua Forssk. Edgew. (Capparidaceae) normally known as Khair is a wonderful source of alkaloids, terpenoids, glycosides, and some fatty acids. The plant has significant hypercholesterolemic, anti-inflammatory, analgesic, antidiabetic, antimicrobial, antiplaque, antihypertensive, anthelmintic, and purgative potential [17-21]. Likewise, Ber (Ziziphus jujuba Mill.) of family Rhamnaceae widely grows in southern parts of Khyber Pakhtunkhwa province of Pakistan. The fruits and seeds are used for antifungal, antibacterial, antiulcer, anti-inflammatory, sedative, antispastic, anti fertility/contraception, hypotensive, and wound healing properties [22].

\section{Materials and Methods}

All the chemical studies including phytochemical screening, antimicrobial activity, antioxidant activity, and polyphenolic content of medicinal plants were conducted at Agricultural Chemistry Department, University of Agriculture, Peshawar, and Pharmacy Department, Peshawar University.

2.1. Plant Collection and Identification. The fresh fruit samples (Ziziphus jujuba, Capparis decidua, Ficus carica, and Syzygium cumini) were collected from different locations of Kohat, Karak, Bannu, and D. I. Khan-Khyber Pakhtunkhwa in 2008-2010. Each fruit along with aerial part of the fruit plant was identified by Mr. Shahid Farooq (Plant Taxonomist, PCSIR, Peshawar). A set of voucher specimens of each plant was deposited in the herbarium of PCSIR, Peshawar.

2.2. Sampling. About $3-5 \mathrm{~kg}$ samples of each plant fruit material were collected from their natural habitat from 4-5 different sites. About $1-2 \mathrm{~kg}$ representative sample of each plant was thoroughly mixed and immediately washed of dust, impurities, and other adhering materials using tap water. The fruit sample was then dried at room temperature under shade for 4-5 days or until the fruits were completely dried. The dried samples were first ground into small pieces by use of mortar and pestle and then into fine powder by use of electrical grinder. These powdered samples were sealed in plastic bags and stored in refrigerator until they were analyzed.

2.3. Extraction. The powder plants samples were macerated in aqueous methanol for primary extraction. The filtrates were then evaporated using rotary evaporator.

2.4. Phytochemical Screening. Phytochemical screening of the subject samples for the qualitative identification of tannins, saponins, terpenoids, steroids, and flavonoids was done by various analytical techniques. Standard procedure was used for screening of the constituents as described by [2325].

2.4.1. Determination of Tannins. About $0.5 \mathrm{~g}$ dry powder of each sample was boiled in $20 \mathrm{~mL}$ of water in a test tube and then filtered. Few drops of $0.1 \%$ ferric chloride solution were added and noticed for brownish green or blue-black coloration [24].

2.4.2. Determination of Saponins. About $2 \mathrm{~g}$ of the powder sample was boiled in $20 \mathrm{~mL}$ of distilled water on a water bath and filtered. $10 \mathrm{~mL}$ filtrate was mixed with $5 \mathrm{~mL}$ of distilled water and shaken vigorously for a stable persistent froth. Then, the froth was mixed with 3 drops of olive oil and shaken vigorously, till emulsion formed [23].

2.4.3. Determination of Flavonoids. Approximately $5 \mathrm{~mL}$ of the dilute ammonia solution was added to a portion of the aqueous filtrate of each plant extract followed by addition of concentrated $\mathrm{H}_{2} \mathrm{SO}_{4}$. A yellow coloration was observed in each extract indicating the presence of flavonoids. The yellow coloration disappeared on standing [24].

2.4.4. Determination of Terpenoids. About $5 \mathrm{~mL}$ of each plant extract was mixed with $2 \mathrm{~mL}$ of chloroform and after mixing about $3 \mathrm{~mL}$ concentrated $\mathrm{H}_{2} \mathrm{SO}_{4}$ was carefully added to form a layer. A reddish brown coloration of the inner face will be formed indicating the presence of terpenoids [25].

2.4.5. Determination of Steroids. About $20 \mathrm{~g}$ of each plant sample was soaked in ethanol in a conical flask. The sample containing ethanol was warmly heated in water bath and then filtered. In this process the ethanol fraction was extracted and then the alcohol portion was evaporated from the filtrate by placing it in water bath in a large size watch glass. The solid sample left behind was dissolved in chloroform. Now acetic anhydride $4.5 \mathrm{~mL}$ and sulfuric acid $0.5 \mathrm{~mL}$ were added. During the experiment the color of the extract changed from violet to green, which was indicating the presence of steroids [23].

2.4.6. Total Polyphenols Determination. Total polyphenolic content of the crude fractions of subject plants was evaluated through the FCR method in which the gallic acid was used as standard. $100 \mu \mathrm{l}$ of each plant sample was taken and subsequently $900 \mu \mathrm{l}$ of distilled water was added to 
TABLE 1: Ethnobotanical information of selected species of subject area used as food and medicine.

\begin{tabular}{|c|c|c|c|c|c|c|c|}
\hline S. number & $\begin{array}{l}\text { Botanical } \\
\text { name }\end{array}$ & Family & Local name & Life form & Parts used & $\begin{array}{c}\text { Mode/form of } \\
\text { consumption }\end{array}$ & $\begin{array}{l}\text { Perceived traditional } \\
\text { ethnobotanical use }\end{array}$ \\
\hline 1 & $\begin{array}{c}\text { Capparis } \\
\text { decidua } \\
\text { Edgew }\end{array}$ & Capparidaceae & Karir & Shrub & Flower and fruit & $\begin{array}{l}\text { Raw, dried, semicooked, } \\
\text { and used in making } \\
\text { pickles }\end{array}$ & $\begin{array}{l}\text { Dietary and } \\
\text { medicinal }\end{array}$ \\
\hline 2 & $\begin{array}{l}\text { Ficus carica } \\
\text { Forssk }\end{array}$ & Moraceae & Inzar (Injeer) & $\begin{array}{c}\text { Shrub/small } \\
\text { tree }\end{array}$ & $\begin{array}{l}\text { Milky latex and } \\
\text { fruits }\end{array}$ & $\begin{array}{l}\text { Raw, dried, decoction, } \\
\text { eaten fresh, and used in } \\
\text { salad, jam, marmalade, } \\
\text { and bakery products }\end{array}$ & $\begin{array}{l}\text { Dietary and } \\
\text { medicinal }\end{array}$ \\
\hline 3 & $\begin{array}{l}\text { Syzygium } \\
\text { cumini L. }\end{array}$ & Myrtaceae & Jaman & Tree & $\begin{array}{l}\text { Fruits, seeds, } \\
\text { leaves, and bark }\end{array}$ & $\begin{array}{l}\text { Raw and extracts and } \\
\text { used in salad, jam, } \\
\text { jellies, refreshing drinks, } \\
\text { and other sweet food } \\
\text { products }\end{array}$ & $\begin{array}{c}\text { Dietary and } \\
\text { medicinal (diabetes) }\end{array}$ \\
\hline 4 & $\begin{array}{c}\text { Ziziphus } \\
\text { jujuba Mill. }\end{array}$ & Rhamnaceae & Baira & Tree & $\begin{array}{l}\text { Leaves, bark, } \\
\text { and fruits }\end{array}$ & $\begin{array}{l}\text { Raw, decoction, and } \\
\text { dried }\end{array}$ & $\begin{array}{l}\text { Dietary and } \\
\text { medicinal }\end{array}$ \\
\hline
\end{tabular}

the samples, after which $0.5 \mathrm{~mL}$ of FCR was added to the mixture. $20 \%$ of the $\mathrm{Na}_{2} \mathrm{CO}_{3}$ solution was made. From this solution $1.5 \mathrm{~mL}$ was taken and added into the above mixture (sample + water + FCR). The whole mixture was placed in volumetric flask on water bath and heated for about 2 hours. After the cooling of the mixture, UV-vis spectrophotometer was employed to measure the absorbance at the wavelength of $720 \mathrm{~nm}$. Total polyphenolic contents in samples were assessed by using gallic acid equivalent (GAE) as standard [26].

2.4.7. Total Flavonoid Contents Determination. Total flavonoid content of the crude fraction of each of the samples was evaluated through the calorimetric method in which Quercetin was taken as standard. One $\mathrm{mL}$ of each sample was taken and $4 \mathrm{~mL}$ of distilled water was added. To this mixture sodium nitrate and $\mathrm{Alcl}_{3}$ were added at the concentration mixture of $300 \mu \mathrm{l}$. The total volume was then incubated for 5 minutes followed by the addition of $2 \mathrm{~mL}$ of $\mathrm{NaOH}$; the volume was increased up to $10 \mathrm{~mL}$. UV-vis spectrophotometer was used for absorbing the wavelength set at $510 \mathrm{~nm}$ and total flavones were then expressed as Quercetin equivalents in $\mathrm{mg} / \mathrm{g}$ of dry samples.

\subsection{Antioxidant Activity}

2.5.1. DPPH Radical Scavenging Assay. The powdered material of the subject plants was extracted with methanol for $36-48 \mathrm{~h}$. The solvent after extraction of each sample was evaporated at low temperature under reduced pressure in rotary vacuum evaporator to obtain crude extracts.

Antioxidant activity was determined by using the 2,2diphenyl-1-picrylhydrazyl (DPPH) radical scavenging assay as described by [27-30]. DPPH (1 mL, $0.3 \mathrm{mM})$ solution in ethanol was added to $2.5 \mathrm{~mL}\left(100 \mathrm{mg} \mathrm{mL}^{-1}\right)$ of methanol extract and mixture was allowed to react for $30 \mathrm{~min}$ at room temperature and absorbance was recorded using UV visible spectrophotometer at $518 \mathrm{~nm}$. HPLC grade Rutin hydrate (95\%, $1 \mathrm{mM})$ was used as standard, while absolute ethanol was used as negative control. The experiment was repeated in triplicate, using fresh plant sampled each time, and the average absorbance values were converted to percentage antioxidant activity.

2.6. Antibacterial and Antifungal Activities. Bacterial and fungal strains tests were performed on three bacteria and two fungi reference strains. Bacterial strains were Escherichia coli, Bacillus subtilis, and Staphylococcus aureus while fungal strains include Trichophyton longifusus (clinical isolate) and Candida albicans. They were maintained on agar slant at $48^{\circ} \mathrm{C}$. The strains were activated at $378^{\circ} \mathrm{C}$ for $24 \mathrm{hr}$ on nutrient agar or Sabouraud glucose agar (SGA), respectively, for bacteria and for fungi, prior to any screening [31].

2.7. Minerals Assay. Dried and ground leaves samples were wet digested for minerals as stated by [32] in 1:1 mixture of $\mathrm{HNO}_{3}-\mathrm{HClO}_{4}$ by gradually increasing the temperature up to $300^{\circ} \mathrm{C}$. Trace elements such as iron $(\mathrm{Fe})$, copper $(\mathrm{Cu})$, zinc $(\mathrm{Zn})$, manganese $(\mathrm{Mn})$, and selenium $(\mathrm{Se})$ were determined using double beam atomic absorption spectrophotometer Perkins Elmer Model 2380.

\section{Results and Discussion}

In the present study, four wild plants found in southern parts of Khyber Pakhtunkhwa were investigated for their dietary and pharmacological potential. These plants (Capparis decidua, Ficus carica, Syzygium cumini, and Ziziphus jujuba) were investigated for secondary metabolites using phytochemical screening, biochemical compounds and mineral content, antimicrobial potential, and antioxidant activity. In the present study, selected ethnobotanical information is displayed in Table 1. This information was obtained during the collection time from the native populace. The study of literature also confirmed its ethnobotanical potential [18-20]. These plants are separately used by local dwellers. Although various parts of the examined plants are used for different purposes, the fruit parts are very popular among the people. The fruit part of Capparis decidua plant is known as karir 
or kary which is edible and also used in various forms of processed food like pickles and making sweet food products. The flowers are used as a vegetable and commonly consumed with loaf and meat. The Ficus carica locally known as Inzar is widely distributed in different parts of Khyber Pakhtunkhwa. Fruit and latex are routinely used for dietary and medicinal purposes. The fruit part is used in both fresh and dried forms and it is also used in making sweet food products like cake and bakery making $[33,34]$.

Syzygium cumini locally known as Jaman is very famous for its dietary and medicinal values. The leaves, fruit, seeds, and bark are very effective against anti-inflammatory activity, asthma, diarrhea, fever, diabetes, and other common ailments [35]. The fruits are consumed in different parts of Pakistan as fresh raw fruit as such or in salad or processed in jams, squash, and so forth. Similarly the Ziziphus jujuba plant is commonly known as baira and it is one of the widely grown plants of southern parts of Khyber Pakhtunkhwa. The fruit is liked by people of all ages and used both in dried and in fresh forms. It is also used in sweet food products making and used for the eradication of bronchitis, diarrhoea, dysentery, cold, and coughs.

Phytochemicals are natural bioactive compound widely distributed in plants, animals, microbes, and other forms of life. The principal examples of natural products including alkaloids, terpenoids, steroids, polyphenols, and flavonoids have rational uses and are found in varying amounts in different species. Their presence in the food chains has significant role which is to work with nutrients and dietary fibre to protect against disease [36-38]. Nevertheless, their presence in foods has traditionally been regarded as antinutritional factor [39] and in some cases has limited their use due to their bitter taste $[40,41]$.

In the present study, the preliminary phytochemical screening of the subject plants reveals that they are good sources of natural products. The results concluded that the studied plants contained appreciable amount of tannins, flavonoids, steroids, alkaloids, and saponins; however terpenoids content was almost negligible (Table 2). The results regarding flavonoids and tannins were very promising in the investigated plants. The preliminary phytochemical screening of Syzygium cumini and Ziziphus jujuba showed promising results for the presence of saponins, tannins, terpenoids, and flavonoids while the examined plants revealed the least level of steroids concentration in the crude aqueous methanolic extract. Similarly, Borhade [42] reported that flavonoids, tannins, steroids, and saponins are the main constituents in the Syzygium cumini plant. It is confirmed from the literature that larger amount of flavonoids might be responsible for their healing effect against pathogenic microorganisms [43]. Similarly, saponins concentration is appreciable in Capparis decidua and Ficus carica and has the property of binding with cholesterol, bitterness, and hemolytic activity in aqueous solution [44].

In the present study all the four subject plants were investigated for total polyphenols and flavonoids content and their results are oscillated in Table 3 . Phenols are the key component of many biocompounds like salicylic acid (aspirin) and recent literature studies reported that thousands
TABLE 2: Phytochemical screening of methanolic extract of investigated samples.

\begin{tabular}{lcccc}
\hline Names & $\begin{array}{c}\text { Capparis } \\
\text { decidua }\end{array}$ & $\begin{array}{c}\text { Ficus } \\
\text { carica }\end{array}$ & $\begin{array}{c}\text { Syzygium } \\
\text { cumini }\end{array}$ & $\begin{array}{c}\text { Ziziphus } \\
\text { jujuba }\end{array}$ \\
\hline Tannins & ++ & ++ & ++ & ++ \\
Flavonoids & ++ & ++ & ++ & ++ \\
Alkaloids & ++ & ++ & ++ & ++ \\
Phenols & ++ & ++ & ++ & ++ \\
Saponins & - & ++ & ++ & ++ \\
Steroids & ++ & ++ & ++ & ++ \\
\hline
\end{tabular}

++ : present and -: absent.

of novel and variant phenolic compounds were identified and discovered in different biological sources. They are the key unit in all the foods we normally consume. The primary role of their presence in our diets is acting as antioxidant, antiseptic, and anti-inflammatory and for the eradication of other different human aliments. They also have nuisance effect when applied directly to the skin.

Flavonoids are hydroxylated phenolic substances, responsible for their therapeutic potency against wide array of microorganisms, probably due to their ability to complex with extracellular and soluble proteins and to complex with the bacterial cell wall. Flavonoids and other phenolic compounds are potent water soluble antioxidants and free radical scavengers, which prevent oxidative cell damage and have strong anticancer activity $[45,46]$.

The aim of this test was to evaluate the absorbing capacity of subject plants in two different fractions (hexane and methanol) by using Folin-Ciocalteu reagent. Gallic acid was used as standard to evaluate the results obtained. The results showed total phenolic content and total flavonoid contents were found in promising amount in all the studied plants ranging from 4 to $31 \mathrm{mg} \mathrm{GAE} / \mathrm{g}$ and from 3 to $43 \mathrm{mg}$ Quercetin/g, respectively. The maximum content of total phenolic compound was observed in methanolic fraction of Syzygium cumini $(31.2 \pm 3.15 \mathrm{mg} \mathrm{GAE} / \mathrm{g})$ followed by Capparis decidua $(23.2 \pm 3.15 \mathrm{mg} \mathrm{GAE} / \mathrm{g})$ and low level of the content was found in hexane fraction of Syzygium cumini $(4.2 \pm 3.28 \mathrm{mg} \mathrm{GAE} / \mathrm{g})$. Similarly, the flavonoid content of the Capparis decidua was maximum in methanolic extract (43.46 $\pm 12.52 \mathrm{mg}$ Quercetin/g) and low level of the content was found in hexane fraction of Ziziphus jujuba (3.25 \pm $1.35 \mathrm{mg}$ Quercetin/g).

Research has confirmed that subject plants possess total phenolic and flavonoids contents which are of enormous benefits for mankind, thus ratifying our findings. The antioxidant support we get from investigated plants is largely due to their phenolic compounds that have been shown to help protect us against unwanted oxygen damage to our cells, blood vessels, and organ systems [47]. Antioxidant compounds in food play an important role as a health protecting factor. Scientific evidence suggests that antioxidants reduce the risk for chronic diseases including cancer and heart disease. It is increasingly being realized that many of today's diseases are due to the "oxidative stress" that results from an imbalance 
TABLE 3: The phytochemical constituents (flavonoid extract and total phenolic content) of selected plants form the studied area.

\begin{tabular}{lcccc}
\hline \multirow{2}{*}{ Samples/extracts } & \multicolumn{2}{c}{ Total phenolic contents* SD } & \multicolumn{2}{c}{ Total flavonoid** Content \pm SD } \\
& Hexane extract & Me.OH extract & Hexane extract & $43.46 \pm 12.52$ \\
Capparis decidua Edgew & $11.15 \pm 4.32$ & $23.2 \pm 3.15$ & $26.60 \pm 12.28$ & $36.60 \pm 12.28$ \\
Ficus carica Forssk & $5.95 \pm 2.47$ & $16.95 \pm 3.23$ & $26.95 \pm 7.17$ & $25.2 \pm 3.15$ \\
Syzygium cumini L. & $4.2 \pm 3.28$ & $31.2 \pm 3.15$ & $13.2 \pm 3.15$ & $3.25 \pm 1.35$ \\
Ziziphus jujuba Mill & $5.78 \pm 2.17$ & $21.74 \pm 4.35$ & & $15.66 \pm 3.87$ \\
\hline
\end{tabular}

${ }^{*} \mathrm{mg} \mathrm{GAE} / \mathrm{g}$ of extract and ${ }^{* *} \mathrm{mg}$ Quercetin equivalent/g of extract.

TABLE 4: Antioxidant activity (\%) of the studied plants found from various regions of KPK.

\begin{tabular}{lccc}
\hline Plant species & \multicolumn{3}{c}{ Concentration $(\mathrm{mg})$} \\
\hline Capparis decidua & 0.25 & 0.50 & 1.00 \\
Ficus carica Forssk & 27.3 & 12.3 & 15.5 \\
Syzygium cumini L. & 35.0 & 19.1 & 10.9 \\
Ziziphus jujuba & 34.9 & 41.1 & 63.3 \\
\hline
\end{tabular}

between formation and neutralization of prooxidants. Oxidative stress is initiated by free radicals; hence, all human beings protect themselves against free radical damage somehow by antioxidant supplements, which are vital to combat oxidative damage. It is also called free radical scavenging activity because of its ability to scavenge free radicals. Free radical generation is directly related with oxidation in foods and biological systems. Therefore, the search for potential free radical scavenging agent is imperative and indispensable.

Table 4 displays the percent antioxidant activity of studied plants using 2,2-diphenyl-1-picrylhydrazyl (DPPH) radical. In this study, three different concentrations were selected $(0.25,0.50$, and $1.00 \mathrm{mg})$. It was observed that highest antioxidant activity was observed in $1.00 \mathrm{mg}$ content of Syzygium cumini (63.3\%) followed by Ziziphus jujuba (47.3\%), Capparis decidua (15.5\%), and Ficus carica (10.9\%), respectively. However, slightly different trends were observed in analyzing the 0.25 and $0.5 \mathrm{mg}$ content of the examined plants. In this case, Ficus carica exhibited maximum antioxidant activity at $0.5 \mathrm{mg}$ level (27.3\%) followed by $0.25 \mathrm{mg}$ level (19.5\%).

In the present research study, methanolic crude extracts of Capparis decidua, Ficus carica, Syzygium cumini, and Ziziphus jujuba were evaluated for antimicrobial potential (Table 5). They were investigated against three different bacterial strains (E. coli, P. aeruginosa, and S. typhi) and two different fungal strands including Trichophyton longifusus and Candida albicans. Minimum inhibitory concentrations of the effective extracts were estimated by agar dilution method. The results were compared with that of standard drug.

Similarly, $P$. aeruginosa is a frequent cause of nosocomial infections such as pneumonia, urinary tract infections (UTIs), and bacteremia [48]. Salmonella typhi is the main food poisoning agent and typhoid fever that is a major public health problem worldwide.

Likewise, the pathogenic fungi Trichophyton longifusus are responsible for the infections of dermatophytosis in the hair, skin, and nails of humans due to their ability to utilize keratin as a source of nourishment. Another fungal strain Candida albicans is responsible for the candidiasis which affects various body parts including ear, mouth, throat, skin, scalp, fingers, toes, nails, bronchi, lungs, and intestine gastrointestinal tract. Factors predisposing people to candidiasis include AIDS, burn patients, young individual, pregnancy, oral birth control, high fruit diets, steroids, antibiotic therapy, immune suppressants, cancer treatments, heart surgery, genetic deficiency, and endocrine deficiency diabetes.

Results of the study divulged that Capparis decidua, Ficus carica, Syzygium cumini, and Ziziphus jujuba had potent antibacterial agent against E. coli, S. typhi, and P. aeruginosa. It was observed that crude methanolic fraction of Ficus carica, Syzygium cumini, and Ziziphus jujuba exhibited good level of activity against all investigated strains. Similarly, the Ziziphus jujuba is effective against $E$. coli showing MIC value of $0.60 \pm$ 0.1 and is least effective against $P$. aeruginosa. E. coli is one of the most frequent agents of many bacterial infections. The major diseases caused by this strain are cholecystitis, bacteremia, cholangitis, urinary tract infection, diarrhoea, neonatal meningitis, and pneumonia [49]. Similarly, Ficus carica and Syzygium cumini exhibited activity against both bacterial and fungal strains. The possible reasons of this activity might be due to the presence of phytochemicals. The literature studies reveal that these natural products have significant role in the biological and pharmacological activity.

Likewise, the investigated plants were also analysed for the elemental composition. Mean values of the data reported in Table 6 showed that manganese and iron are found in maximum concentration followed by zinc whereas $\mathrm{Cr}$ is found in minimum level. Manganese showed a concentration ranging from 0.53 to $12 \mathrm{mg} 100^{-1} \mathrm{~g}$. It has been reported previously that chromium nutrition leads to decreased requirement for insulin and improved blood lipid profile [50]. It is observed that zinc is present with promising concentration of $1.3 \mathrm{mg}$ $100^{-1} \mathrm{~g}$ in Capparis decidua. Nevertheless, it was found that the subject plants are good sources of these minerals and they might be beneficial in the eradication of certain diseases.

\section{Conclusion}

The current study showed that the investigated plants' fruits of all four plants are good sources of iron, zinc, copper, manganese, selenium, and chromium. It was also observed that these fruits are potential source of antioxidant agent and 
TABLE 5: Antimicrobial (antifungal and antibacterial) assay at $5 \mathrm{mg} / \mathrm{mL}$ of methanolic crude extracts of selected plants (average value \pm SD, $\mu \mathrm{g} / \mathrm{mL})$.

\begin{tabular}{lccccc}
\hline Fractions & $E C$ & $P A$ & $S T$ & $T L$ & \multicolumn{1}{c}{ CA } \\
\hline Capparis decidua & $17.7 \pm 6.58$ & $11.16 \pm 2.05$ & $0.96 \pm 0.1$ & $0.82 \pm 0.28$ & $1.11 \pm 0.50$ \\
Ficus carica & $0.74 \pm 0.15$ & $0.67 \pm 0.24$ & $0.12 \pm 0.03$ & 0.30 & $0.5 \pm 0.2$ \\
Syzygium cumini & $0.73 \pm 0.20$ & $10.0 \pm 1.64$ & $0.54 \pm 0.23$ & $0.46 \pm 0.15$ & $0.46 \pm 0.01$ \\
Ziziphus jujuba & $0.60 \pm 0.1$ & $3.40 \pm 0.49$ & $0.93 \pm 0.16$ & $0.85 \pm 0.07$ & 0.1 \\
Cipro/Ampho.B & 0.06 & 1.5 & 0.25 & 0.5 \\
\hline
\end{tabular}

EC: E. coli; PA: P. aeruginosa; ST: S. typhi, TL: Trichophyton longifusus; CA: Candida albicans. Cipro and Ampho.B (standard drug), SD: standard deviation.

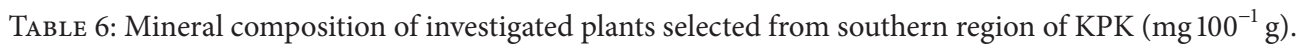

\begin{tabular}{lcccc}
\hline Elements & Capparis decidua & Ficus carica & Syzygium cumini & Ziziphus jujuba \\
\hline Iron & $6.13 \pm 0.15$ & $9.07 \pm 2.45$ & $1.90 \pm 0.30$ & $7.40 \pm 0.20$ \\
Zinc & $1.30 \pm 0.10$ & $3.00 \pm 1.50$ & $1.17 \pm 0.58$ & $2.57 \pm 0.30$ \\
Copper & $2.50 \pm 0.10$ & $4.63 \pm 1.52$ & $1.37 \pm 0.13$ & $1.34 \pm 0.05$ \\
Manganese & $12.30 \pm 0.20$ & $7.12 \pm 2.10$ & $6.33 \pm 0.58$ & $0.53 \pm 0.08$ \\
Selenium & $0.25 \pm 0.08$ & $0.39 \pm 0.58$ & $0.35 \pm 0.05$ & $0.41 \pm 0.22$ \\
Chromium & $0.46 \pm 0.11$ & $1.57 \pm 0.47$ & ND & ND \\
\hline
\end{tabular}

Values are for triplicate determination (mean $\pm \mathrm{SD}$ ).

the possible reason could be that these samples had good amount of phytochemicals. Hence, the proper propagation, conservation, and chemical investigation are recommended so that these fruits should be incorporated for the eradication of food and health related problems.

\section{Conflict of Interests}

The authors have declared that they have no conflict of interests.

\section{Acknowledgment}

The authors are thankful to the Deanship of Scientific Research, King Saud University, Riyadh, for funding the work through the research group Project no. RGP-210.

\section{References}

[1] P. K. Vayalil, "Antioxidant and antimutagenic properties of aqueous extract of date fruit (Phoenix dactylifera L. Arecaceae)," Journal of Agricultural and Food Chemistry, vol. 50, no. 3, pp. 610-617, 2002.

[2] J. A. Vinson, L. Zubik, P. Bose, N. Samman, and J. Proch, "Dried fruits: excellent in vitro and in vivo antioxidants," The Journal of the American College of Nutrition, vol. 24, no. 1, pp. 44-50, 2005.

[3] G. A. Agbor, P. Moumbegna, E. O. Oluwasola et al., "Antioxidant capacity of some plant foods and beverages consumed in the Eastern Region of Nigeria," African Journal of Traditional, Complementary, and Alternative Medicines, vol. 8, no. 4, pp. 362-369, 2011.

[4] L. R. Fukumoto and G. Mazza, "Assessing antioxidant and prooxidant activities of phenolic compounds," Journal of Agricultural and Food Chemistry, vol. 48, no. 8, pp. 3597-3604, 2000.
[5] M. Valko, D. Leibfritz, J. Moncol, M. T. D. Cronin, M. Mazur, and J. Telser, "Free radicals and antioxidants in normal physiological functions and human disease," International Journal of Biochemistry and Cell Biology, vol. 39, no. 1, pp. 44-84, 2007.

[6] H. Sies, "Oxidative stress: oxidants and antioxidants," Experimental Physiology, vol. 82, no. 2, pp. 291-295, 1997.

[7] D. Prakash and K. R. Gupta, "The antioxidant phytochemicals of nutraceutical importance," The Open Nutraceuticals Journal, vol. 2, pp. 20-35, 2009.

[8] J. K. Grover, S. Yadav, and V. Vats, "Medicinal plants of India with anti-diabetic potential," Journal of Ethnopharmacology, vol. 81, no. 1, pp. 81-100, 2002.

[9] J. A. Vinson, Y. Hao, X. Su, and L. Zubik, "Phenol antioxidant quantity and quality in foods: vegetables," Journal of Agricultural and Food Chemistry, vol. 46, no. 9, pp. 3630-3634, 1998.

[10] T. K. Pilvi, S. Harala, R. Korpela, and E. M. Mervaala, "Effects of high-calcium diets with different whey proteins on weight loss and weight regain in high-fat-fed C57BL/6J mice," British Journal of Nutrition, vol. 102, no. 3, pp. 337-341, 2009.

[11] P. Dhan, C. Gupta, and G. Sharma, "Importance of phytochemicals in nutraceuticals," Journal of Chinese Medicine Research and Development, vol. 1, no. 3, pp. 70-78, 2012.

[12] D. L. Watts, "Nutrient interrelationships: minerals, vitamins, endocrines," Journal of Orthomolecular Medicine, vol. 5, no. 1, pp. 11-19, 1990.

[13] M. E. Kislev, A. Hartmann, and O. Bar-Yosef, "Early domesticated fig in the Jordan Valley," Science, vol. 312, no. 5778, pp. 1372-1374, 2006.

[14] M.-R. Jeong, H.-Y. Kim, and J.-D. Cha, "Antimicrobial activity of methanol extract from Ficus carica leaves against oral bacteria," Journal of Bacteriology and Virology, vol. 39, no. 2, pp. 97-102, 2009.

[15] R. Veberic, M. Colaric, and F. Stampar, "Phenolic acids and flavonoids of fig fruit (Ficus carica L.) in the northern Mediterranean region," Food Chemistry, vol. 106, no. 1, pp. 153-157, 2008.

[16] S. Shweta, B. K. Mehta, M. Darshna, N. Hemant, and M. Aditya, "A review on pharmocoligical activity of Syzygium 
cumini extracts usisng different solvents and their effective uses," International Research Journal of Pharmacy, vol. 3, pp. 5458, 2012.

[17] M. Zia-Ul-Haq, S. Ćavar, M. Qayum, I. Imran, and V. de Feo, "Compositional studies: antioxidant and antidiabetic activities of Capparis decidua (Forsk.) Edgew," International Journal of Molecular Sciences, vol. 12, no. 12, pp. 8846-8861, 2011.

[18] B. Joseph and D. Jini, "A medicinal potency of Capparis decidua-a harsh terrain plant," Research Journal of Phytochemistry, vol. 5, no. 1, pp. 1-13, 2011.

[19] P. Singh, G. Mishra, S. Srivastava, K. K. Jha, and R. L. Khosa, "Traditional uses, phytochemistry and pharmacological properties of Capparis decidua: an Overview," Der Pharmacia Lettre, vol. 3, no. 2, pp. 71-82, 2011.

[20] M. U. Dahot, "Chemical evaluation of the nutritive value of flowers and fruits of Capparis decidua," Journal of the Chemical Society of Pakistan, vol. 15, no. 1, pp. 78-81, 1993.

[21] S. Rathee, P. Rathee, D. Rathee, and V. Kumar, "Phytochemical and pharmacological potential of kair (Capparis Decidua)," International Journal of Phytomedicine, vol. 2, no. 1, pp. 10-17, 2010.

[22] L.-M. Li, X. Liao, S.-L. Peng, and L.-S. Ding, "Chemical constituents from the seeds of Ziziphus jujuba var. spinosa (Bunge) Hu," Journal of Integrative Plant Biology, vol. 47, no. 4, pp. 494-498, 2005.

[23] A. Sofowara, Medicinal Plants and Traditional Medicine in Africa, Spectrum Books, Ibadan, Nigeria, 1993.

[24] G. E. Trease and W. C. Evans, Pharmacognosy, Braille Tirideland Macmillan Publishers, 2nd edition, 1989.

[25] J. B. Harborne, Phytochemical Methods, Chapman \& Hall, London, UK, 1973.

[26] R. J. Grubešić, J. Vuković, D. Kremer, and S. Vladimir-Knežević, "Spectrophotometric method for polyphenols analysis: prevalidation and application on Plantago L. species," Journal of Pharmaceutical and Biomedical Analysis, vol. 39, no. 3-4, pp. 837-842, 2005.

[27] W. Brand-Williams, M. E. Cuvelier, and C. Berset, "Use of a free radical method to evaluate antioxidant activity," LWT-Food Science and Technology, vol. 28, no. 1, pp. 25-30, 1995.

[28] A. Kamkar, A. J. Javan, F. Asadi, and M. Kamalinejad, "The antioxidative effect of Iranian Mentha pulegium extracts and essential oil in sunflower oil," Food and Chemical Toxicology, vol. 48, no. 7, pp. 1796-1800, 2010.

[29] J. Liu, Q. Li, J. Dong, J. Chen, and G. Gu, "Multivariate modeling of aging in bottled lager beer by principal component analysis and multiple regression methods," Journal of Agricultural and Food Chemistry, vol. 56, no. 16, pp. 7106-7112, 2008.

[30] C.-C. Lee, W.-C. Chang, and S.-C. Wu, "The antimutagenic and antioxidative activity for functional formula beverage," Taiwanese Journal of Agricultural Chemistry and Food Science, vol. 47, no. 6, pp. 277-284, 2009.

[31] A. W. Bauer, W. M. Kirby, J. C. Sherris, and M. Turck, "Antibiotic susceptibility testing by a standardized single disk method," The American Journal of Clinical Pathology, vol. 45, no. 4, pp. 493496, 1996.

[32] AOAC (Association of Official Analytical Chemists), Official Methods of Analysis, Edited by W. Horwitz, AOAC, Arlington, Va, USA, 15th edition, 2000.

[33] A. H. Gilani, M. H. Mehmood, K. H. Janbaz, A.-U. Khan, and S. A. Saeed, "Ethnopharmacological studies on antispasmodic and antiplatelet activities of Ficus carica," Journal of Ethnopharmacology, vol. 119, no. 1, pp. 1-5, 2008.
[34] A. Solomon, S. Golubowicz, Z. Yablowicz et al., "Antioxidant activities and anthocyanin content of fresh fruits of common fig (Ficus carica L.)," Journal of Agricultural and Food Chemistry, vol. 54, no. 20, pp. 7717-7723, 2006.

[35] P. S. Benherlal and C. Arumughan, "Chemical composition and in vitro antioxidant studies on Syzygium cumini fruit," Journal of the Science of Food and Agriculture, vol. 87, no. 14, pp. 25602569, 2007.

[36] D. T. Gordon, D. Stoops, and V. Ratliff, "Dietary fiber and mineral nutrition," in Dietary Fiber in Health \& Disease, D. Kritchevsky and C. Bonfield, Eds., Eagan Press, Eagan, Minn, USA, 1995.

[37] M. A. Sanjoaquin, P. N. Appleby, E. A. Spencer, and T. J. Key, "Nutrition and lifestyle in relation to bowel movement frequency: a cross-sectional study of 20630 men and women in EPIC-Oxford," Public Health Nutrition, vol. 7, no. 1, pp. 77-83, 2004.

[38] D. L. Topping and P. M. Clifton, "Short-chain fatty acids and human colonic function: roles of resistant starch and nonstarch polysaccharides," Physiological Reviews, vol. 81, no. 3, pp. 10311064, 2001.

[39] L. U. Thompson, "Potential health benefits and problems associated with antinutrients in foods," Food Research International, vol. 26, no. 2, pp. 131-149, 1993.

[40] C. P'ei and S. L. Chen, "Verbenaceae," Flora Reipublicae Popularis Sinicae, vol. 65, pp. 1-229, 1982.

[41] C. L. Ridout, K. R. Price, M. S. DuPont, M. L. Parker, and G. R. Fenwick, "Quinoa saponins-analysis and preliminary investigations into the effect of reduction by processing," Journal of the Science of Food and Agriculture, vol. 54, pp. 165-176, 1991.

[42] S. Borhade, "Antibacterial activity, phytochemical analysis of water extract of Syzygium cumini and analytical study by HPLC," Asian Journal of Experimental Biological Sciences, vol. 3, no. 2, pp. 320-324, 2012.

[43] M. M. Cowan, "Plant products as antimicrobial agents," Clinical Microbiology Reviews, vol. 12, no. 4, pp. 564-582, 1999.

[44] O. A. Sodipo, J. A. Akiniyi, and J. U. Ogunbamosu, "Studies on certain characteristics of extracts of bark of pansinystalia macruceras (K schemp) pierre Exbeille," Global Journal of Pure and Applied Sciences, vol. 6, pp. 83-87, 2000.

[45] N. Salah, N. J. Miller, G. Paganga, L. Tijburg, G. P. Bolwell, and C. Rice-Evans, "Polyphenolic flavanols as scavengers of aqueous phase radicals and as chain-breaking antioxidants," Archives of Biochemistry and Biophysics, vol. 322, no. 2, pp. 339-346, 1995.

[46] D. E. Okwu, "Phytochemicals and vitamin content of indigenous spices of South Eastern Nigeria," Journal of Sustainable Agriculture and the Environment, vol. 6, pp. 30-34, 2004.

[47] A. Scalbert, C. Manach, C. Morand, C. Rémésy, and L. Jiménez, "Dietary polyphenols and the prevention of diseases," Critical Reviews in Food Science and Nutrition, vol. 45, no. 4, pp. 287306, 2005.

[48] K. J. Ryan and C. G. Ray, Sherris Medical Microbiology: An Introduction to Infectious Disease, McGraw-Hill, New York, NY, USA, 4th edition, 2004.

[49] M. A. Bisi-Johnson and C. L. Obi, "Escherichia coli and Salmonella species: molecular landscape and therapeutic considerations: a review," Advances in Medical Sciences, vol. 1, no. 1, pp. 1-16, 2012.

[50] M. K. Hellerstein, "Is chromium supplementation effective in managing type II diabetes?” Nutrition Reviews, vol. 56, no. 10, pp. 302-306, 1998. 

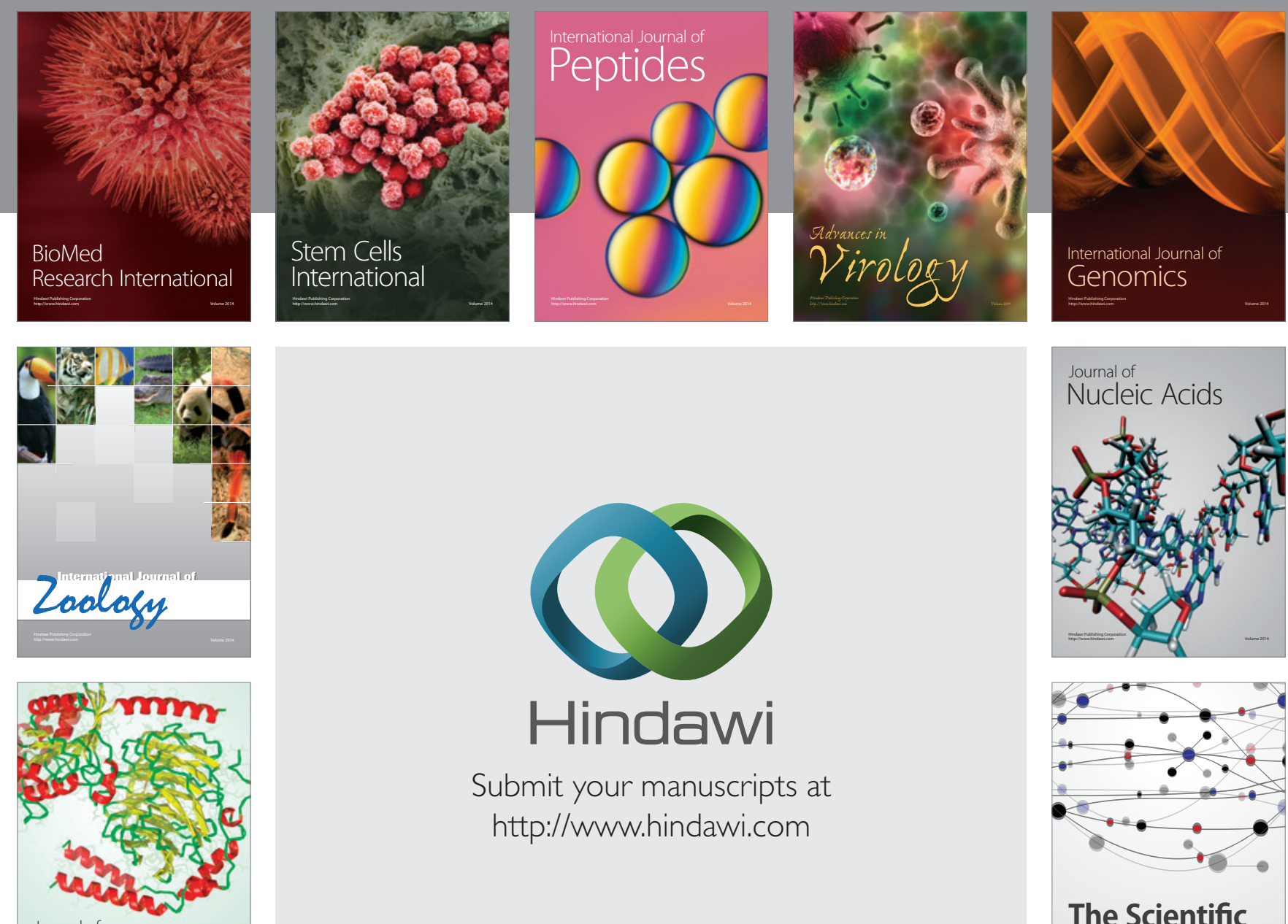

Submit your manuscripts at

http://www.hindawi.com

Journal of
Signal Transduction
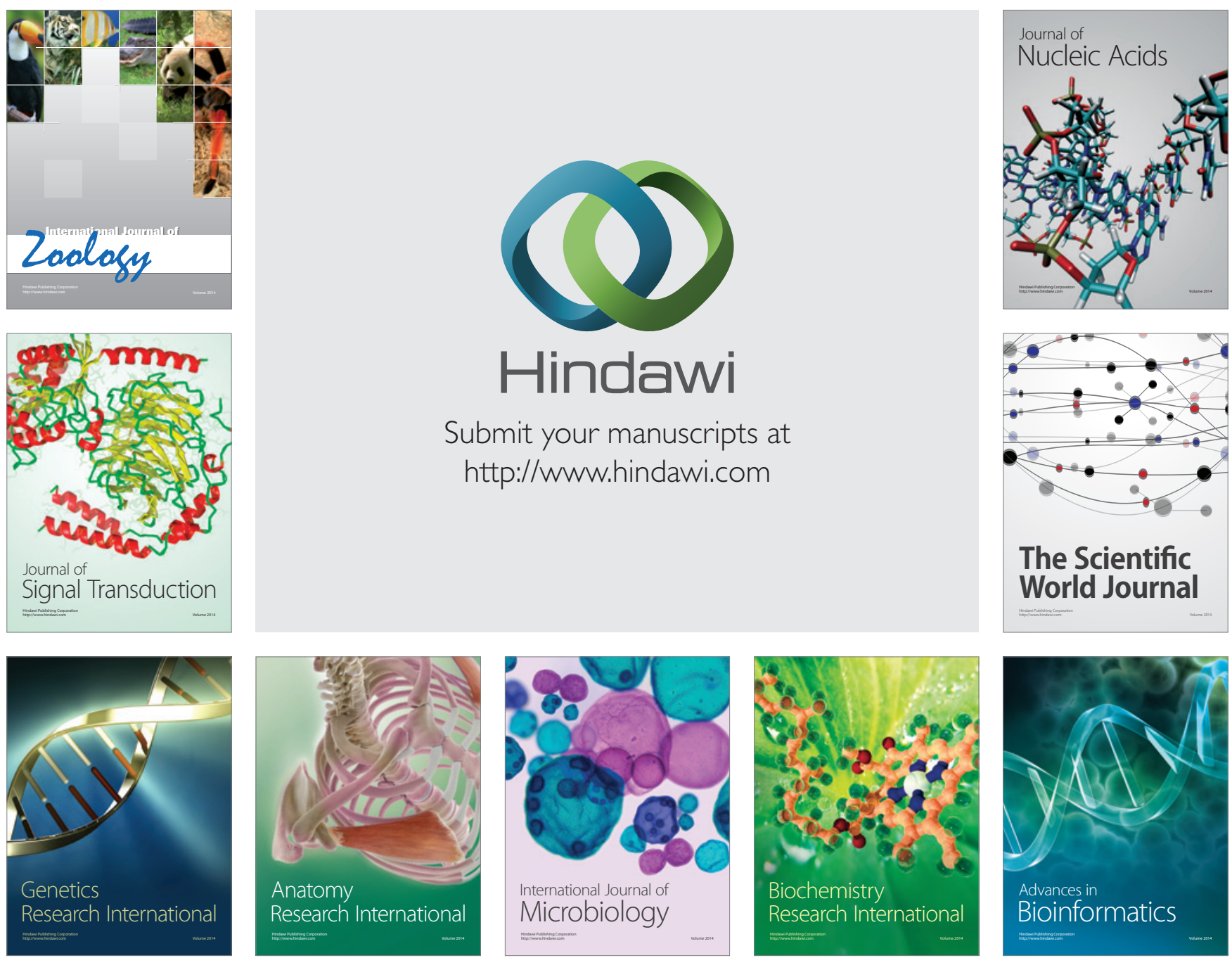

The Scientific World Journal
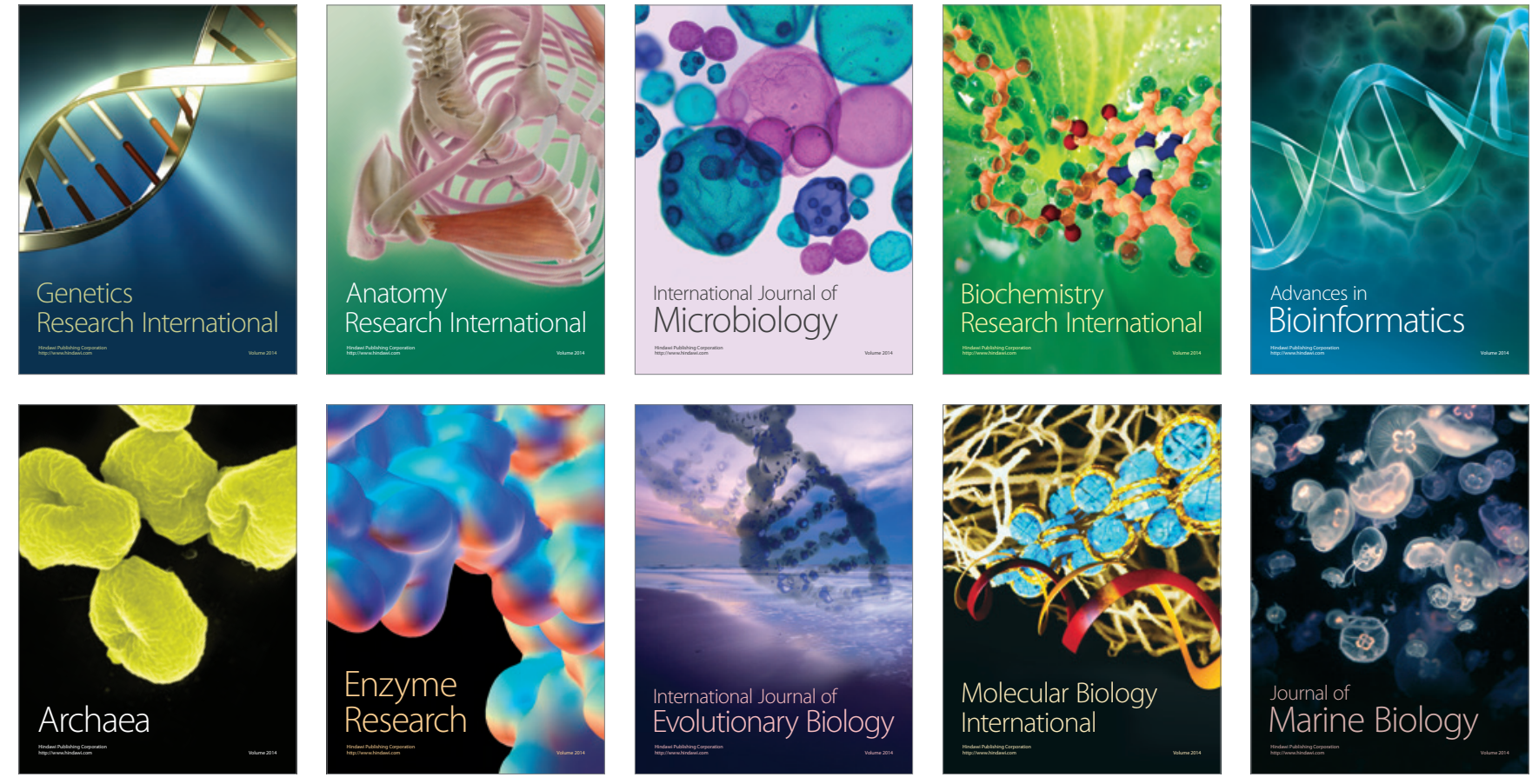